\title{
28 Research Square \\ Gestational vinclozolin exposure suppresses fetal Leydig cell development in rats
}

\section{Keyang Wu}

Wenzhou Medical University Second Affiliated Hospital

Yang Li

Wenzhou Medical University Second Affiliated Hospital

\section{Peipei Pan}

Wenzhou Medical University Second Affiliated Hospital

\section{Zengqiang Li}

Wenzhou Medical University Second Affiliated Hospital

\section{Yige Yu}

Wenzhou Medical University Second Affiliated Hospital

\section{Feifei Ma}

Wenzhou Medical University Second Affiliated Hospital

\section{Lili Tian}

Wenzhou Medical University Second Affiliated Hospital

\section{Yinghui Fang}

Wenzhou Medical University Second Affiliated Hospital

\section{Yiyan Wang}

Wenzhou Medical University Second Affiliated Hospital

\section{Ren-Shan Ge ( $\sim$ r_ge@yahoo.com )}

Wenzhou Medical University Second Affiliated Hospital https://orcid.org/0000-0002-3448-9823

\section{Research}

Keywords: vinclozolin, fetal Leydig cell, Sertoli cell, testosterone, autophagy

Posted Date: February 14th, 2020

DOI: https://doi.org/10.21203/rs.2.23589/v1

License: (9) (1) This work is licensed under a Creative Commons Attribution 4.0 International License. Read Full License 


\section{Abstract}

Background: Vinclozolin is not only a common dicarboximide fungicide used to protect crops against diseases but also an endocrine disruptor. This study aimed to investigate the effects of gestational vinclozolin exposure on the development of rat fetal Leydig cells.

Methods: Female pregnant Sprague-Dawley rats were exposed to vinclozolin $(0,25,50$, and $100 \mathrm{mg} / \mathrm{kg}$ body weight/day) by oral gavage from gestational day 14 to 21 .

Results: Vinclozolin dose-dependently depressed serum testosterone levels at doses of 50 and 100 $\mathrm{mg} / \mathrm{kg}$ and anogenital distance at $100 \mathrm{mg} / \mathrm{kg}$. RNA-seq, qPCR, and Western blot showed that vinclozolin down-regulated the expression of Nr5a1, Sox9 , Lhcgr, Cyp11a1, Hsd3b1 , Hsd17b3 , Amh , Pdgfa , and Dhh and their encoded proteins. Vinclozolin depressed NR2F2-positive stem Leydig cell number at a dose of $100 \mathrm{mg} / \mathrm{kg}$ and also enhanced autophagy in the testis.

Conclusion: Vinclozolin disrupts fetal Leydig cell development via several pathways.

\section{Background}

The reproductive tract anomalies, including hypospadias and cryptorchidism, have been assumed to be associated with the action of some endocrine disruptors in mammals [1]. Agricultural reliance on fungicides in the modern society has caused people being exposed to numerous endocrine disruptors, including vinclozolin (VCZ).

VCZ is a dicarboximide fungicide that is widely applied in the field in controlling fungi on vegetables, fruits, and ornamental plants. Humans can contact VCZ via ingestion of foods, vegetables, and fruits, inhalation of dust particles, and dermal absorption. U.S. Environmental Protection Agency (EPA) estimated that VCZ exposure would be $2.933 \mu \mathrm{g}$ per $\mathrm{kg}$ a day general people [2].

VCZ has been thought to be an environmental contaminant that binds to the androgen receptor (NR3C4, a nuclear receptor) to cause anti-androgenic effects as an antagonist [3]. The transient administration of VCZ to pregnant female rats at the time of embryonic sex determination promoted defects in the reproductive tract and subfertility of the F1 male offspring [4]. The in utero VCZ exposure to the pregnant dams caused abnormalities of the androgen-regulated sexual differentiation in the male offspring, including shortening of the anogenital distance (AGD) [5-7]. VCZ-exposed male offspring during gestation developed the retained nipples, cleft phallus, hypospadias, cryptorchidism, small ventral prostate, seminal vesicles, and epididymis, as well as reduced sperm counts [5-7]. However, the underlying mechanism is poorly understood on a molecular level.

Development of the male reproductive tract relies on the differentiation of the fetal gonads, which includes the differentiation of somatic cells, such as fetal Leydig cells (FLCs) and Sertoli cells (SCs). FLCs, differentiated from stem Leydig cells (SLCs)[8], secrete testosterone (T) and insulin-like 3 (INSL3) 
for induction of testis descent and the differentiation of the Wolffian ducts into the male reproductive tracts. SCs, developed from their precursor cells under the action of sex-determining region Y-box 9 (SOX9) [9], secrete anti-müllerian hormone $(\mathrm{AMH})$ to cause the apoptosis of müllerian ducts [10]. In addition, SCs secrete many growth factors, such as platelet growth factor A (PDGFA), AMH, and desert hedgehog (DHH) to control FLC development [11]. This study aimed to investigate the effects of gestational VCZ exposure on the development of rat FLCs and to explore the underlying mechanism.

\section{Methods}

\section{Chemicals}

The detailed materials and methods were described in the Supplementary material S1. General toxicological parameters after treatment of vinclozolin were described in Table1. Chemicals, reagents, kits, software, and equipment were described in Table2. Antibody sources and information were described in Table3. Primer information was described in Table4.

\section{Animals and experimental design}

The animal model used in the current study was the Sprague-Dawley rat. Adult female and male SpragueDawley rats (56 days of age, weighed at $220 \pm 10 \mathrm{~g}$ ) were purchased from the Shanghai Laboratory Animal Center (Shanghai, China). Rats were allowed one week to acclimate to the experimental environment. Time-pregnant female rats were randomly assigned into different treatment groups: 0, 25, 50 , and $100 \mathrm{mg} / \mathrm{kg} /$ day VCZ ( $=8$ rats/group). The experimental protocol for animal toxicity experiment was approved by Wenzhou Medical University Laboratory Animal Ethics Committee. The experiment was performed following the procedures described in the Guide for the Care and Use of Laboratory Animals published by the United States National Institutes of Health.

VCZ was suspended in corn oil (vehicle control). Daily gavage dosing of the dams started on GD 14 and continued until the initiation of parturition at doses of $0,25,50$, or $100 \mathrm{mg} / \mathrm{kg}$. Dose selection is based on the observation that VCZ significantly caused anomalies of the male reproductive tracts of rats at 200$400 \mathrm{mg} / \mathrm{kg}$ [12]. Body weights of dams were daily recorded. Male pups were euthanized by $\mathrm{CO}_{2}$. Blood and testis of each male pup was collected for the following studies.

\section{Measurement of serum T level}

Serum T level was detected by the Siemens Healthcare Diagnostics Total Testosterone Kit as previously described [13]. The inter-assay and intra-assay coefficients of variation were within $15 \%$.

\section{Histochemical hematoxylin staining}

The incidence of multinucleated gonocytes (MNGs) in the fetal testis can be increased by some endocrine-disrupting chemicals [14-16]. The occurrence rate of MNGs after VCZ treatment was counted as previously described [13]. In brief, cross-sections were sliced at $6 \mu \mathrm{m}$ from a testis tissue-array by 
microtome and stained with hematoxylin solution as previously described [17]. The percentage of the seminiferous cord containing MNGs was calculated.

\section{Immunohistochemical staining}

CYP11A1 is used as the biomarker of the FLC [18]. Transcription factor SOX9 is used as the biomarker of the SC [19]. The total numbers of CYP11A1-positive cell and SOX9-positive cells were counted by a fractionator technique as previously described [20]. In brief, fetal testes were embedded in paraffin block in a tissue-array block, cross-sections were sliced and stained immunohistochemically with CYP11A1 or SOX9. Immunohistochemical staining method was used as previously described [21].

\section{Computer-assisted analysis of FLC metrics}

The FLC metrics include cell, nuclear, and cytoplasmic sizes, which were measured as previously described [22]. In brief, cell and nuclear sizes were measured by the Media Cybernetics Image-Pro 6 Plus software, with the measurement parameter of the average area.

\section{Semi-quantitative immunohistochemical measurement of CYP11A1 and SOX9}

Immunohistochemical staining of CYP11A1 and SOX9 were performed as described [22]. Target protein density and surrounding area background density were measured by the Media Cybernetics Image-Pro 6 Plus with the measurement parameter of the main density.

\section{Measurement of FLC proliferation}

The proliferation of FLCs was measured by immunofluorescent staining of proliferating cell nuclear antigen (PCNA) and CYP11A1 as previously described [23]. In brief, the cross-sections in the tissue-array congregated above were utilized. Sections were double-labeled with the primary antibodies of CYP11A1 and PCNA followed by the fluorescent secondary antibody.

\section{Measurement of stem Leydig cell number}

Previous studies demonstrated that FLCs were developed from stem Leydig cells [8, 24]. Stem Leydig cells in the fetal testis are spindle-shaped and express NR2F2, also called COUP-TFII [8, 24-26]. We used NR2F2 as the biomarker to identify the stem Leydig cell and SOX9 as the biomarker to draw a boundary for the seminiferous cord. Double immunofluorescent staining was performed as above. The number of NR2F2-positive cells per square millimeter was calculated.

\section{Preparation of RNA-seq library}

Eight testes per dam were randomly selected for total RNA isolation. Total RNAs were extracted from testes using Invitrogen Trizol Kit as previously described [27]. Total RNAs were enriched by oligo-dT magnetic beads and RNA-seq library was set up by Illumina KAPA Stranded RNA-Seq Library Prep Kit. The libraries were sequenced on the Illumina HiSeq 4000 instrument. 


\section{RNA-seq analysis}

We performed RNA-seq of the testis and biological pathway analysis to address the pathway of VCZmediated action in vivo as previously described [28]. Gene expression level, Gene Ontology, Pathway analysis, scatter plots, and volcano plots were performed.

\section{Biological pathway analysis}

Biological pathway analysis was performed as previously described [29]. In brief, the GenMAPP2.1 software was used to create a map of signal pathways for the potential pathways.

\section{Quantitative real-time PCR (qPCR)}

We performed the qPCR of VCZ-treated samples to verify the sequencing data of the testes and to measure the levels of some mRNAs that were not detectable by RNA-seq as previously described [30]. The mRNA levels of Lhcgr, Scarb1, Star, Cyp11a1, Hsd3b1, Cyp17a1, Hsd17b3, Ins/3, Nr5a1, Pcna, Pdgfa, Amh, Dhh, and Sox9 were analyzed using the SYBR Green qPCR Kit. Lhcgr, Scarb1, Star, Cyp11a1, Hsd3b1, Cyp17a1, Hsd17b3, were Ins/3 were FLC genes. Pdgfa, Amh, Dhh, and Sox9 are SC genes, and $\mathrm{Nr} 5 \mathrm{a} 1$ is the critical transcription factor for the development of both FLCs and SCs. Pcna is the proliferating cell biomarker. The mRNA levels were determined by a standard curve method.

\section{Western blot}

Western blot was performed as previously described [28]. In brief, testis is lysed, denatured, electrophoresed and blotted with the primary antibody followed by the secondary antibody. Blots were stripped and incubated with a monoclonal GAPDH antibody served as the internal control.

\section{Measurement of serum IGF-1}

Insulin-like growth factor 1 (IGF-1) plays important roles in cell proliferation, differentiation and growth of many cells, including Leydig cells [11,31]. The circulatory IGF-I is mainly produced by mammalian livers [31]. IGF-1 ELISA kit was used for the measurement of serum IGF-I according to the manufacturer's instruction.

\section{Statistical analysis}

Values for all intents and purposes are expressed as mean \pm S.E.M., and data were analyzed by one-way ANOVA followed ad hoc Turkey's analysis to specifically compare values from VCZ-treated rats to the control. GraphPad Prism was used.

\section{Results}

VCZ shortens AGD and depresses serum T levels in male pups 
Eight dams per group were orally administered via gavage of $0,25,50$, and $100 \mathrm{mg} / \mathrm{kg} /$ day VCZ for 10 days from GD 14 to 21 (Fig.1A). Body weights of dams and pups after VCZ treatment were without change (Supplementary material S5). Birth rate, pup number per dam, male birth weights and percent male ratio were without change either (Supplementary material S5). However, VCZ significantly depressed AGD at $100 \mathrm{mg} / \mathrm{kg}$ (Fig.1B), indicating that VAC is an anti-androgen. We measured serum T levels in male pups. VCZ significantly depressed serum T levels in male pups at doses of 50 and $100 \mathrm{mg} / \mathrm{kg}$ (Fig.1C), suggesting that VCZ disrupts FLC steroidogenesis.

\section{VCZ does not alter incidence of MNGs}

Some endocrine disruptors, such as phthalates, can disrupt germ development, increasing the incidence of MNGs in the fetal testis [14,32]. The rate of MNGs after VCZ treatment was counted. VCZ did not alter MNG incidence in the fetal testis (Supplementary Fig.S1).

\section{VCZ deceases FLC cluster size}

FLCs exist as single cell or a cluster of FLCs with two or more cells [33]. In the current study, we defined the cluster size for FLCs as single (one cell per cluster), small (2-4 cells per cluster), medium (5-16 cells per cluster), and large (>16 cells per cluster). VCZ showed slight increase of FLC number at $100 \mathrm{mg} / \mathrm{kg}$, but no significance was observed when compared to the control (Fig.2A-E). VCZ significantly depressed the percentage of medium-size FLC cluster (Fig.2F). This indicates that VCZ might disrupt the growth of FLC clusters. We also analyzed FLC metrics (cell and cytoplasmic sizes) and did not find any change of these two parameters (Fig.2G and $2 \mathrm{H}$ ).

\section{VCZ does not change PCNA labeling index of FLCs}

We performed double-staining of CYP11A1 for FLCs and PCNA for the proliferating cell. VCZ did not alter the percentage of PCNA labeling index of FLCs (Supplementary Fig.S2), confirming the above finding that unaltered FLC number was observed after VCZ treatment.

\section{VCZ lowers NR2F2-positive stem Leydig cell number}

Previous studies indicated that NR3C4 is critical for Leydig cell development [34,35] because stem Leydig cells express NR3C4 [36]. VCZ is an NR3C4 antagonist. We used NR2F2 as a biomarker of stem Leydig cells to identify their number. Indeed, NR2F2 is expressed in the spindle-shaped cells in the interstitial area (Fig.3A-B). VCZ significantly lowered NR2F2-positive cell number in the interstitial compartment (Fig.3C). This indicates that VCZ disrupts stem Leydig cell number.

\section{VCZ does not affect SC number}

SCs were marked by biomarker SOX9. VCZ did not affect SC number (Supplementary Fig.S3). This indicates that the proliferation of SCs is not influenced by VCZ. 
We examined the effects of VCZ on testicular gene expression using RNA-Seq analysis. We sequenced the transcripts and 8848 transcripts were identified in the testis between control and $25-100 \mathrm{mg} / \mathrm{kg} \mathrm{VCZ}$ groups. We particularly analyzed the difference between $100 \mathrm{mg} / \mathrm{kg} \mathrm{VCZ}$ and the control. As shown in Supplementary Fig.S4A (volcanoplot), of these transcripts, 107 transcripts were significantly up-regulated $(P<0.05)$ and 101 transcripts were significantly down-regulated $(P<0.05)$ in the $100 \mathrm{ng} /$ testis VCZ group (Supplementary Fig.S4A). GO analysis identified that most of down-regulated genes were within regulation of protein catabolism, protein acylation, peptidyl-lysine acetylation and that most of upregulated genes were within regulation of cellular protein catabolism, protein amino acid acetylation, peptidyl-lysine acetylation, inner cell mass proliferation, histone H2B ubiquitination, and histone acetylation (Supplementary FigS.4B). Heatmap listed the down-regulated (Supplementary Fig.S4C) and up-regulated (Supplementary Fig.S4D) genes.

\section{Pathway analysis reveals VCZ-induced down-regulation of steroidogenesis and regulation pathway}

In the steroidogenic pathway, we found Cyp11a 1 was down-regulated by ${ }^{3} 2$ folds at 25, 50 and 100 $\mathrm{mg} / \mathrm{kg} \mathrm{VCZ} \mathrm{(Fig.4).} \mathrm{We} \mathrm{also} \mathrm{found} \mathrm{that} \mathrm{two} \mathrm{critical} \mathrm{transcription} \mathrm{factors} \mathrm{of} \mathrm{regulating} \mathrm{FLC} \mathrm{development}$ and steroidogenesis, Nr5a 1 and Nr4a1, were significantly down-regulated at doses of 25, or 50 and 100 $\mathrm{mg} / \mathrm{k} \mathrm{VCZ}$. Further pathway analysis showed that Gli transcription factor in the hedgehog pathway was down-regulated at $100 \mathrm{mg} / \mathrm{kg}$ VCZ (Fig.4). We used qPCR to measure other FLC and SC gene expression. We found that VCZ down-regulated expression of FLC steroidogenesis-related genes ( Lhcgr, Hsd3b1, and Hsd17b3) at $100 \mathrm{mg} / \mathrm{kg}$ (Fig.5). Since the development of FLCs is regulated by SC-secreted growth factors, such as PDGFA (encoded by Pdgfa) [37], AMH (encoded by Amh) [38] and DHH (encoded by Dhh) [39], which was regulated by SC transcription factor SOX9 (encoded by Sox9) [40], we measured these gene expression in SCs. VCZ lowered transcript levels of SC genes (Pdgfa, Amh, Dhh, and Sox9) at 25 $\mathrm{mg} / \mathrm{kg}$ and higher doses (Fig.5). This indicates that the FLC differentiation is blocked, in part by the down-regulation of SC-secreted growth factors.

\section{VCZ lowers FLC and SC protein levels}

We further performed Western blot for FLC proteins (LHCGR, CYP11A1, HSD3B1, and HSD17B3), SC proteins (PDGFA, AMH, DHH, SOX9) and FLC/SC common protein (NR5A1). It was found that VCZ lowered their levels at 25 or higher doses (Fig.6). IGF-1 was primarily secreted by liver and also was critical for the regulation of FLC development [41]. We performed ELISA to measure IGF-1 level in the serum of male offspring and found that VCZ decreased IGF-1 level at $100 \mathrm{mg} / \mathrm{kg}$. Semi-quantitative immunohistochemical staining for CYP11A1 density per FLC and SOX9 density per SC showed that VCZ lowered CYP11A1 and SOX9 densities at doses of 50 and $100 \mathrm{mg} / \mathrm{kg}$ (Supplementary Fig.S5). These data further confirm qPCR data.

\section{VCZ induces autophagy in fetal testis in vivo}

Previous studies indicated that many environmental chemicals induced autophagy to disrupt Leydig cell function $[42,43]$. Western blot showed that VCZ significantly induced autophagy in the testis tissues with 
increases in LC3-II and beclin-1 proteins and decrease in p62 at $100 \mathrm{mg} / \mathrm{kg}$ (Fig.7). This indicates that VCZ can induce autophagy in the testis as a protective mechanism.

\section{Discussion}

Here, we found that gestational exposure of VCZ to male fetuses inhibited T synthesis, decreased expression of several genes linked with the steroidogenesis of the testis.

We reported that VCZ shortened AGD at doses of 50 and $100 \mathrm{mg} / \mathrm{kg}$. This is consistent with the observations from the exposure to 100 or $200 \mathrm{mg} / \mathrm{kg} /$ day VCZ from GD 14 through postnatal day 3 [44]. A prenatal exposure study for $0,3.125,6.25,12.5,25,50$, or $100 \mathrm{mg} / \mathrm{kg} \mathrm{VCZ}$ by gavage from GD 14 to postnatal day 3 further showed that VCZ at doses of $3.125 \mathrm{mg} / \mathrm{kg}$ and above had a dose-dependent response for shortening AGD and increasing incidence of retained areolas [45].

The effects of VCZ on the development of the fetal male reproductive tract have been hypothesized to be contributed by NR3C4 antagonism of VCZ. However, VCZ itself had a weak N3C4 antagonistic effect. VCZ have two major VCZ metabolites (M1 and M2) after it is metabolized by liver enzymes. M1 and M2 effectively antagonized the NR3C4 binding to the rat NR3C4 in vitro [46]. VCZ, M1, and M2 had the Ki values of $>700,92$, and $9.7 \mu \mathrm{M}$ to replace dihydrotestosterone binding to rat NR3C4 [46]. The potency of NR3C4 binding is M2 > M1 > VCZ [46]. Further study demonstrated that M2 is able to block androgenbound NR3C4 complex to the androgen response element on NR3C4 targeted DNA, thus blocking NR3C4induced transactivation [47].

Within the fetal testis, VCZ or its metabolites might act on NR3C4 of testicular cells. In the fetal rat testis, NR3C4 is primarily present in interstitial cells surrounding the seminiferous cords [48]. As the fetal testis develops, NR3C4 is found in peritubular myoid cells and elongated mesenchymal cells (presumably stem Leydig cells) [48]. Indeed, VCZ can lower the NR2F2-positive stem Leydig cell number at the highest dose (Fig. 3). Previous studies indicated that FLCs do not express NR3C4 [48] and in mouse, NR3C4 appears in SCs after birth [49]. In this regard, NR3C4 antagonism by VCZ and its metabolites cannot completely explain its mechanisms. Other targets including SOX9 and NR5A1 might be involved.

Previous studies showed that fetal development of SCs involved the Sox9 gene, which encodes SOX9 to initiate a cascade of molecular processes to promote the differentiation of SC precursor cells after the activation by SRY [19]. VCZ can down-regulate the expression of Sox 9 and its protein during gestational exposure (Figs. 4 and 5), confirming the previous report of in utero VCZ exposure to lower SOX9 expression [50]. Exploration of the downstream targets of SOX9 has identified several genes, including Pdgfa [51] and Amh [52, 53]. VCZ lowered transcript levels of SC genes, including Pdgfa, Dhh, Amh, and Sox9 as well as $\mathrm{Nr5a1}$ (Fig. 5) and their protein (Fig. 6) levels.

It has been demonstrated that SOX9 was able to bind the Pdgfa promoter to increase its expression in the fetal mouse testis [51]. PDGFA, the product of Pdgfa, was reported to be the pivotal factor to guide FLC differentiation because knockout of PDGFA receptor (Pdgfra) resulted in the disrupted FLC development 
in the fetus with reduced steroidogenesis in mice [37] and null mutation of PDGFA also blocked Leydig cell development in mice during puberty [54].

Desert hedgehog (Dhh) is another critical gene, which is expressed in SCs. It encodes DHH, which binds to the $\mathrm{DHH}$ receptor, $\mathrm{PTCH} 1$, to initiate a cascade to increase Gli expression to regulate FLC development [39]. Null mutation of DHH can block the FLC development [39] and Leydig cell differentiation during puberty [55]. Indeed, VCZ decreased the expression of Dhh and Gli (Figs. 4 and 5), thus interfering with FLC development.

Interestingly, the promoter analysis also showed that Cyp11a1 and Hsd3b1 were the targets of SOX9 [56]. Therefore, the significant down-regulation of SOX9 also led to the reduction of expression of Cyp11a1 and Hsd3b1.

$\mathrm{Nr} 5 \mathrm{a} 1$, which is a gene expressed downstream of Sry, has a significant role in gonadal being a transcriptional activator of steroidogenic enzymes and other genes that are essential for androgen biosynthesis (Parker and Schimmer, 1997) and it also promotes SC differentiation via stimulating SOX9 and down-stream gene expression [57]. In the present study, we also demonstrated that VCZ significantly lowered $\mathrm{Nr} 5 \mathrm{a} 1$ expression (Figs. 4 and 5).

Autophagy is a highly-regulated lysosomal degradation involving the delivery of cytoplasmic cargo to the lysosome [58]. Autophagy can be induced during growth factor withdrawal in order to generate more intracellular nutrients [59] and under stressful conditions such as chemical exposure $[43,60]$. Autophagy

is characterized by increased expression of autophagy-related proteins, such as LC3-I to LC3-II conversion and beclin-1 as well as a decreased expression of p62 [61]. Adequate autophagy is important for maintaining the Leydig cell function [62] because it is able to reduce ROS accumulation by clearing damaged mitochondria [63]. Indeed, in the current study, we demonstrated that autophagy of testis was increased as shown by the increase of LC3-II and beclin-1 levels and a decrease of p62 levels (Fig. 7). This could be due to the decrease of growth factors such as circulatory IGF-1 (Fig. 6) or PDGFA, AMH, and $\mathrm{DHH}$ locally in the testis (Fig. 6). This indicates that the increased autophagy after VCZ exposure at the highest dose is the protective mechanism for fetal testis function.

\section{Conclusion}

Our data show that VCZ exposure inhibits the secretion of growth factors such as PDGFA, AMH, and DHH after down-regulating expression of SOX9, thus blocking the differentiation of FLCs, leading to low T synthesis (Supplementary FigS6). At the high dose, VCZ also activates the autophagy pathway to count its effects.

\section{Additional Files}

\section{Supplementary Material S1}


Supplementary Figure $\mathbf{S 1}$ Incidence of multinucleated gonocytes after in utero vinclozolin treatment

Panels A-D, H\&E staining images at $0,25,50$, and $100 \mathrm{mg} / \mathrm{kg}$ vinclozolin (VCZ), respectively; Panel B, quantitative data; Inset is the magnified field; Arrow designates a gonocyte that does not have two or more nuclei; $\mathrm{Bar}=50 \mu \mathrm{m}$. Mean $\pm \mathrm{SEM}, \mathrm{n}=8$; Identical letters designate no significant difference between two groups at $p<0.05$.

\section{Supplementary Figure S2 PCNA-labeling index of fetal Leydig cells after vinclozolin treatment}

Panels A-D: Images at 0, 25, 50, and $100 \mathrm{mg} / \mathrm{kg} /$ day vinclozolin (VCZ); White arrow designates PCNApositive fetal Leydig cell (FLC); Bar $=50 \mu \mathrm{m}$; Panel E, PCNA-labeling index of FLCs. Mean \pm SEM, $n=8$. Identical letters designate no significant difference between the two groups at $p<0.05$.

\section{Supplementary Figure S3 Sertoli cell number after vinclozolin treatment}

Panels A-D: Images at 0, 25, 50, and $100 \mathrm{mg} / \mathrm{kg}$ /day vinclozolin (VCZ); Arrow designates SOX9-positive SC; $B a r=50 \mu m ;$ Panel E, SOX9-positive SCs. Mean \pm SEM, $n=8$. Identical letters designate no significant difference between the two groups at $p<0.05$.

\section{Supplementary Figure S4 RNA-seq analysis of genes after vinclozolin treatment}

Control (c1-c4) and $100 \mathrm{mg} / \mathrm{kg}$ vinclozolin (v1-v4) were compared. Panel A: Volcanoplot of up-regulated (red dot) and down-regulated (blue dot) genes; Panel B: GO analysis of up-regulated and down-regulated genes; Panels $\mathrm{C}$ and D: Heatmap for up-regulated and down-regulated genes, respectively.

\section{Supplementary Figure F5 Semi-quantitative measurement of CYP11A1 and SOX9 density after in utero vinclozolin treatment}

Panels A-D, Histochemical staining images for CYP11A1 at 0, 25, 50, and $100 \mathrm{mg} / \mathrm{kg}$ vinclozolin (VCZ), respectively; Panel E, quantitative data for CYP11A1; Panels F-I, Histochemical staining images for SOX9 at $0,25,50$, and $100 \mathrm{mg} / \mathrm{kg} \mathrm{VCZ}$, respectively; Panel J, quantitative data for SOX9; Arrow designates CYP11A1 and arrowhead designates SOX9; Bar $=20 \mu \mathrm{m}$. Mean $\pm \mathrm{SEM}, \mathrm{n}=8$; Identical letters designate no significant difference between the two groups at $p<0.05$.

\section{Supplementary Figure S6 Illustration of vinclozolin action on Leydig cells}

Vinclozolin (VCZ) targets SOX9 and NR5A1 in Sertoli cells and down-regulates the expression of them, thus leading to lower expression of PDGFA and DHH, which in turns blocks fetal Leydig cell development by down-regulating the expression of Leydig cell genes (Lhcgr, Cyp11a1, Hsd3b1, and Hsd17b3) and their proteins, further leading to low T synthesis. VCZ also targets fetal Leydig cells via down-regulating NR5A1 expression, directly lowering the expression of these Leydig cell genes and proteins.

\section{Declarations}




\section{Ethical Approval and Consent to participate}

The experimental protocol for animal toxicity experiment was approved by Wenzhou Medical University Laboratory Animal Ethics Committee and in conformity with procedures described in the Guide for the Care and Use of Laboratory Animals published by the United States National Institutes of Health.

\section{Consent for publication}

Not applicable.

\section{Availability of data and materials}

All data are included in this published article and its supplementary information files or available from the corresponding author on reasonable request.

\section{Funding}

The research is supported by NSFC (81730042) and Department of Health of Zhejiang Province (11CX29).

\section{Competing interests}

The authors declare that they have no competing interests.

\section{Authors' contributions}

$\mathrm{KW}, \mathrm{YL}, \mathrm{RSG}$ participated in the design of the study, performed the animal

experiments and sample collection, and drafted the manuscript. RSG edited the manuscript. PP, ZL, YG performed the animal study. LT and YF. performed the Western blot. YW drafted the manuscript and performed the analyses on sexual hormones.

\section{Acknowledgements}

We thank Dr Xiaoheng Li for providing standard serum to measure T levels.

\section{References}

1. Krishnan K, Mittal N, Thompson LM, Rodriguez-Santiago M, Duvauchelle CL, Crews D, Gore AC: Effects of the Endocrine-Disrupting Chemicals, Vinclozolin and Polychlorinated Biphenyls, on Physiological and Sociosexual Phenotypes in F2 Generation Sprague-Dawley Rats. Environ Health Perspect 2018, 126(9):97005.

2. EPA: Reregistration eligibility decision (RED). Vinclozolin. Case No. 2740. In. Office of Prevention, Pesticides, and Toxic Substances; 2000. 
3. Buckley J, Willingham E, Agras K, Baskin LS: Embryonic exposure to the fungicide vinclozolin causes virilization of females and alteration of progesterone receptor expression in vivo: an experimental study in mice. Environ Health 2006, 5:4.

4. Anway MD, Leathers C, Skinner MK: Endocrine disruptor vinclozolin induced epigenetic transgenerational adult-onset disease. Endocrinology 2006, 147(12):5515-5523.

5. Hardy MP, Mc GAF, O'Neill LA: Transcriptional regulation of the human TRIF (TIR domain-containing adaptor protein inducing interferon beta) gene. Biochem $J$ 2004, 380(Pt 1):83-93.

6. Schneider S, Kaufmann W, Buesen R, van Ravenzwaay B: Vinclozolin-the lack of a transgenerational effect after oral maternal exposure during organogenesis. Reprod Toxicol 2008, 25(3):352-360.

7. Hass U, Scholze M, Christiansen S, Dalgaard M, Vinggaard AM, Axelstad M, Metzdorff SB, Kortenkamp A: Combined exposure to anti-androgens exacerbates disruption of sexual differentiation in the rat. Environ Health Perspect 2007, 115 Suppl 1:122-128.

8. Kumar DL, DeFalco T: A perivascular niche for multipotent progenitors in the fetal testis. Nat Commun 2018, 9(1):4519.

9. Guo JK, Hammes A, Chaboissier MC, Vidal V, Xing Y, Wong F, Schedl A: Early gonadal development: exploring Wt1 and Sox9 function. Novartis Foundation symposium 2002, 244:23-31; discussion 3142, 253-257.

10. Behringer RR: The mullerian inhibitor and mammalian sexual development. Philos Trans $R$ Soc Lond B Biol Sci 1995, 350(1333):285-288; discussion 289.

11. Ye L, Li X, Li L, Chen H, Ge RS: Insights into the development of the adult Leydig cell lineage from stem Leydig cells. Frontiers in physiology 2017, 8:430.

12. Wolf CJ, LeBlanc GA, Ostby JS, Gray LE, Jr.: Characterization of the period of sensitivity of fetal male sexual development to vinclozolin. Toxicol Sci 2000, 55(1):152-161.

13. Lu H, Zhang H, Gao J, Li Z, Bao S, Chen X, Wang Y, Ge R, Ye L: Effects of perfluorooctanoic acid on stem Leydig cell functions in the rat. Environmental pollution 2019, 250:206-215.

14. Li L, Bu T, Su H, Chen Z, Liang Y, Zhang G, Zhu D, Shan Y, Xu R, Hu Y et al: Inutero exposure to diisononyl phthalate caused testicular dysgenesis of rat fetal testis. Toxicol Lett 2014, 232(2):466474.

15. Mahood IK, McKinnell C, Walker M, Hallmark N, Scott H, Fisher JS, Rivas A, Hartung S, Ivell R, Mason $\mathrm{JI}$ et al: Cellular origins of testicular dysgenesis in rats exposed in utero to di(n-butyl) phthalate. Int $\mathrm{J}$ Andro/ 2006, 29(1):148-154; discussion 181-145.

16. Mahood IK, Scott HM, Brown R, Hallmark N, Walker M, Sharpe RM: In utero exposure to di(n-butyl) phthalate and testicular dysgenesis: comparison of fetal and adult end points and their dose sensitivity. Environ Health Perspect 2007, 115 Suppl 1:55-61.

17. Ge F, Zheng W, Bao S, Wu K, Xiang S, Chen W, Chen X, Mo J, Zhou S, Wang Y et al: In utero exposure to triphenyltin disrupts rat fetal testis development. Chemosphere 2018, 211:1043-1053. 
18. Guo J, Zhou H, Su Z, Chen B, Wang G, Wang CQ, Xu Y, Ge RS: Comparison of cell types in the rat Leydig cell lineage after ethane dimethanesulfonate treatment. Reproduction 2013, 145(4):371-380.

19. Koopman P: Sry and Sox9: mammalian testis-determining genes. Cell Mol Life Sci 1999, 55(6-7):839856.

20. Mendis-Handagama SM, Keeney DS, Hardy MP, Ewing LL: Application of the disector method to enumerate cells in the testis. Annals of the New York Academy of Sciences 1989, 564:86-98.

21. Wu X, Guo X, Wang H, Zhou S, Li L, Chen X, Wang G, Liu J, Ge HS, Ge RS: A brief exposure to cadmium impairs Leydig cell regeneration in the adult rat testis. Sci Rep 2017, 7(1):6337.

22. Liu S, Li C, Wang Y, Hong T, Song T, Li L, Ye L, Lian Q, Ge RS: In utero methoxychlor exposure increases rat fetal Leydig cell number but inhibits its function. Toxicology 2016, 370:31-40.

23. Song T, Wang Y, Li H, Chen L, Liu J, Chen X, Li X, Li X, Li L, Lian Q et al: Parathyroid Hormone-Related Protein Promotes Rat Stem Leydig Cell Differentiation. Frontiers in physiology 2017, 8:911.

24. Defalco T, Saraswathula A, Briot A, Iruela-Arispe ML, Capel B: Testosterone levels influence mouse fetal Leydig cell progenitors through notch signaling. Biol Reprod 2013, 88(4):91.

25. Qin J, Tsai MJ, Tsai SY: Essential roles of COUP-TFIl in Leydig cell differentiation and male fertility. PLoS One 2008, 3(9):e3285.

26. van den Driesche S, Walker M, McKinnell C, Scott HM, Eddie SL, Mitchell RT, Seckl JR, Drake AJ, Smith LB, Anderson RA et al: Proposed role for COUP-TFIl in regulating fetal Leydig cell steroidogenesis, perturbation of which leads to masculinization disorders in rodents. PLOS One 2012, 7(5):e37064.

27. Li L, Li X, Chen X, Chen Y, Liu J, Chen F, Ge F, Ye L, Lian Q, Ge RS: Perfluorooctane sulfonate impairs rat Leydig cell development during puberty. Chemosphere 2018, 190:43-53.

28. Wang Y, Xie L, Tian E, Li X, Wen Z, Li L, Chen L, Zhong Y, Ge RS: Oncostatin M inhibits differentiation of rat stem Leydig cells in vivo and in vitro. Journal of cellular and molecular medicine 2019, 23(1):426-438.

29. Wang Y, Yuan K, Li X, Su Z, Guan H, Su Y, Ge HS, Ge RS: Leukemia inhibitory factor stimulates steroidogenesis of rat immature Leydig cells via increasing the expression of steroidogenic acute regulatory protein. Growth Factors 2016:1-11.

30. Zhang L, Wang $H$, Yang $Y$, Liu $H$, Zhang Q, Xiang Q, Ge R, Su Z, Huang Y: NGF induces adult stem Leydig cells to proliferate and differentiate during Leydig cell regeneration. Biochem Biophys Res Commun 2013, 436(2):300-305.

31. Yakar S, Rosen CJ, Beamer WG, Ackert-Bicknell CL, Wu Y, Liu JL, Ooi GT, Setser J, Frystyk J, Boisclair YR et al: Circulating levels of IGF-1 directly regulate bone growth and density. J Clin Invest 2002, 110(6):771-781.

32. Mahood IK, Hallmark N, McKinnell C, Walker M, Fisher JS, Sharpe RM: Abnormal Leydig Cell aggregation in the fetal testis of rats exposed to di (n-butyl) phthalate and its possible role in testicular dysgenesis. Endocrinology 2005, 146(2):613-623. 
33. Wen Q, Cheng CY, Liu YX: Development, function and fate of fetal Leydig cells. Semin Cell Dev Biol 2016, 59:89-98.

34. Xu Q, Lin HY, Yeh SD, Yu IC, Wang RS, Chen YT, Zhang C, Altuwaijri S, Chen LM, Chuang KH et al: Infertility with defective spermatogenesis and steroidogenesis in male mice lacking androgen receptor in Leydig cells. Endocrine 2007, 32(1):96-106.

35. De Gendt K, Atanassova N, Tan KA, de Franca LR, Parreira GG, McKinnell C, Sharpe RM, Saunders PT, Mason $\mathrm{JI}$, Hartung $S$ et al: Development and function of the adult generation of Leydig cells in mice with Sertoli cell-selective or total ablation of the androgen receptor. Endocrinology 2005, 146(9):4117-4126.

36. Kilcoyne KR, Smith LB, Atanassova N, Macpherson S, McKinnell C, van den Driesche S, Jobling MS, Chambers TJ, De Gendt K, Verhoeven $\mathrm{G}$ et al: Fetal programming of adult Leydig cell function by androgenic effects on stem/progenitor cells. Proc Natl Acad Sci U S A 2014, 111(18):E1924-1932.

37. Brennan J, Tilmann C, Capel B: Pdgfr-alpha mediates testis cord organization and fetal Leydig cell development in the XY gonad. Genes \& development 2003, 17(6):800-810.

38. Josso N, Picard JY, Rey R, di Clemente N: Testicular anti-Mullerian hormone: history, genetics, regulation and clinical applications. Pediatric endocrinology reviews : PER 2006, 3(4):347-358.

39. Yao HH, Whoriskey W, Capel B: Desert Hedgehog/Patched 1 signaling specifies fetal Leydig cell fate in testis organogenesis. Genes \& development 2002, 16(11):1433-1440.

40. Tevosian SG, Albrecht KH, Crispino JD, Fujiwara Y, Eicher EM, Orkin SH: Gonadal differentiation, sex determination and normal Sry expression in mice require direct interaction between transcription partners GATA4 and FOG2. Development 2002, 129(19):4627-4634.

41. Baker J, Hardy MP, Zhou J, Bondy C, Lupu F, Bellve AR, Efstratiadis A: Effects of an Igf1 gene null mutation on mouse reproduction. Mol Endocrinol 1996, 10(7):903-918.

42. Wang Y, Zheng W, Bian X, Yuan Y, Gu J, Liu X, Liu Z, Bian J: Zearalenone induces apoptosis and cytoprotective autophagy in primary Leydig cells. Toxicol Lett 2014, 226(2):182-191.

43. Sun Y, Shen J, Zeng L, Yang D, Shao S, Wang J, Wei J, Xiong J, Chen J: Role of autophagy in di-2ethylhexyl phthalate (DEHP)-induced apoptosis in mouse Leydig cells. Environmental pollution 2018, 243(Pt A):563-572.

44. Gray LE, Jr., Ostby JS, Kelce WR: Developmental effects of an environmental antiandrogen: the fungicide vinclozolin alters sex differentiation of the male rat. Toxicol Appl Pharmacol 1994, 129(1):46-52.

45. Gray LE, Jr., Ostby J, Monosson E, Kelce WR: Environmental antiandrogens: low doses of the fungicide vinclozolin alter sexual differentiation of the male rat. Toxicol Ind Health 1999, 15(1-2):4864.

46. Kelce WR, Monosson E, Gamcsik MP, Laws SC, Gray LEJ: Environmental hormone disruptors: Evidence that vinclozolin developmental toxicity is mediated by antiandrogenic metabolites. Toxicol Appl Pharmacol 1994, 126:276-285. 
47. Kelce WR, Lambright CR, Gray LE, Jr., Roberts KP: Vinclozolin and pp'-DDE alter androgen-dependent gene expression: in vivo confirmation of an androgen receptor-mediated mechanism. Toxicol Appl Pharmacol 1997, 142(1):192-200.

48. Majdic G, Millar MR, Saunders PT: Immunolocalisation of androgen receptor to interstitial cells in fetal rat testes and to mesenchymal and epithelial cells of associated ducts. J Endocrinol 1995, 147(2):285-293.

49. Kaftanovskaya EM, Lopez C, Ferguson L, Myhr C, Agoulnik A: Genetic ablation of androgen receptor signaling in fetal Leydig cell lineage affects Leydig cell functions in adult testis. FASEB J 2015, 29(6):2327-2337.

50. Skinner MK, Bhandari RK, Haque MM, Nilsson EE: Environmentally Induced Epigenetic Transgenerational Inheritance of Altered SRY Genomic Binding During Gonadal Sex Determination. Environmental epigenetics 2015, 1(1):dvv004.

51. Rahmoun M, Lavery R, Laurent-Chaballier S, Bellora N, Philip GK, Rossitto M, Symon A, Pailhoux E, Cammas F, Chung $\mathrm{J}$ et al: In mammalian foetal testes, SOX9 regulates expression of its target genes by binding to genomic regions with conserved signatures. Nucleic acids research 2017, 45(12):71917211.

52. Arango NA, Lovell-Badge R, Behringer RR: Targeted mutagenesis of the endogenous mouse Mis gene promoter: in vivo definition of genetic pathways of vertebrate sexual development. Cell 1999, 99(4):409-419.

53. De Santa Barbara P, Bonneaud N, Boizet B, Desclozeaux M, Moniot B, Sudbeck P, Scherer G, Poulat F, Berta P: Direct interaction of SRY-related protein SOX9 and steroidogenic factor 1 regulates transcription of the human anti-Mullerian hormone gene. Mol Cell Bio/ 1998, 18(11):6653-6665.

54. Gnessi L, Basciani S, Mariani S, Arizzi M, Spera G, Wang C, Bondjers C, Karlsson L, Betsholtz C: Leydig cell loss and spermatogenic arrest in platelet-derived growth factor (PDGF)-A-deficient mice. $J$ Cell Biol 2000, 149(5):1019-1026.

55. Clark AM, Garland KK, Russell LD: Desert hedgehog (Dhh) gene is required in the mouse testis for formation of adult-type Leydig cells and normal development of peritubular cells and seminiferous tubules. Biology of Reproduction 2000, 63(6):1825-1838.

56. Li Y, Zheng M, Lau YF: The sex-determining factors SRY and SOX9 regulate similar target genes and promote testis cord formation during testicular differentiation. Cell reports 2014, 8(3):723-733.

57. Bhandari RK, Haque MM, Skinner MK: Global genome analysis of the downstream binding targets of testis determining factor SRY and SOX9. PLoS One 2012, 7(9):e43380.

58. Kim J, Kim YC, Fang C, Russell RC, Kim JH, Fan W, Liu R, Zhong Q, Guan KL: Differential regulation of distinct Vps34 complexes by AMPK in nutrient stress and autophagy. Cel/ 2013, 152(1-2):290-303.

59. Levine B, Kroemer G: Autophagy in the pathogenesis of disease. Cell 2008, 132(1):27-42.

60. Chiarelli R, Martino C, Agnello M, Bosco L, Roccheri MC: Autophagy as a defense strategy against stress: focus on Paracentrotus lividus sea urchin embryos exposed to cadmium. Cell stress \& chaperones 2016, 21(1):19-27. 
61. Kim KH, Lee MS: Autophagy-a key player in cellular and body metabolism. Nat Rev Endocrinol 2014, 10(6):322-337.

62. Gao H, Liu C, Li W: Assessing Autophagy in the Leydig Cells. Methods Mol Biol 2019, 1854:71-85.

63. Kaminskyy VO, Zhivotovsky B: Free radicals in cross talk between autophagy and apoptosis. Antioxid Redox Signal 2014, 21(1):86-102.

\section{Tables}

Table 1. General toxicological parameters after treatment of vinclozolin

\begin{tabular}{|c|c|c|c|c|}
\hline \multirow[t]{2}{*}{ Parameters } & \multicolumn{4}{|c|}{ Vinclozolin dosage $(\mathrm{mg} / \mathrm{kg})$} \\
\hline & 0 & 25 & 50 & 100 \\
\hline \multicolumn{5}{|l|}{ Body weight (g) } \\
\hline At GD14 & $306.8 \pm 8.8$ & $312.3 \pm 7.0$ & $304.0 \pm 9.2$ & $323.5 \pm 7.1$ \\
\hline At GD21 & $377.4 \pm 17.3$ & $386.5 \pm 8.9$ & $385.4 \pm 8.4$ & $399.5 \pm 9.6$ \\
\hline Pup number & 99 & 113 & 107 & 106 \\
\hline Male pup number & 49 & 64 & 44 & 56 \\
\hline Male pup weight (g) & $6.7 \pm 0.3$ & $6.8 \pm 0.2$ & $6.5 \pm 0.3$ & $6.5 \pm 0.2$ \\
\hline Male pup (\%) & 49.49 & 56.64 & 41.12 & 62.26 \\
\hline
\end{tabular}

Dams of Sprague Dawley rats were gavaged with vinclozolin from gestational day (GD) $14-21$. Values are mean \pm SEM, $\mathrm{n}=8$. No significant difference between two groups was observed.

Table2םThe chemicals, kits, software, and equipment

\begin{tabular}{|c|c|c|c|}
\hline Jame & & & Vendor (City, State) \\
\hline Igilent 2100 Bioanalyzer & & & ThermoFisher Scientific (Shanghai, China) \\
\hline 3CA Protein Assay Kit & & & Takara (Otsu, Japan) \\
\hline 3X53 microscope & & & Olympus (Tokyo, Japan) \\
\hline ICL Kit & & & Pierce (Shanghai, China) \\
\hline jenMAPP2.1software & & & University of California (San Francisco, CA) \\
\hline İaphPad Prism version 6 & & & GraphPad Software Inc. (San Diego, CA) \\
\hline mageJ software & & & NIH (Bethesda, MD) \\
\hline mage-Pro 6 Plus software & & & Media Cybernetics (Silver Spring, MD) \\
\hline $\begin{array}{l}\text { MMULITE }{ }^{\circledR} \quad 2000 \quad \text { Immunoassay } \\
\text { eestosterone Kit }\end{array}$ & System and & Total & $\begin{array}{l}\text { Siemens Healthcare Diagnostics Products Limited (Gwynedd, } \\
\text { UK) }\end{array}$ \\
\hline llumina HiSeq 4000 instrument & & & Illumina (Foster City, CA) \\
\hline GF-1 ELISA kit & & & Chemicon (Temecula, CA) \\
\hline JanoDrop (ND-1000) & & & Thermo-Fisher (Redwood City, CA) \\
\hline iNA-Seq & & & Kang-Chen Bio-Tech (Shanghai, China) \\
\hline ;olexa pipeline v1.8 & & & Illumina (Foster City, CA) \\
\hline ;prague Dawley rats & & & Animal Center of Shanghai (Shanghai, China) \\
\hline juper-Signal West Pico substrate & & & Pierce Biotechnology (Radford, IL) \\
\hline ;YBR Green qPCR Kit & & & Takara (Otsu, Japan) \\
\hline rizol Kit & & & Invitrogen (Carlsbad, CA) \\
\hline Tector ABC Kit & & & Vector (Burlingame, CA) \\
\hline Tinclozolin & & & Sigma (St. Louis, MO) \\
\hline
\end{tabular}


Table3. Information of antibodies

\begin{tabular}{lllll}
\hline Antibody & Species & Vendor (City, State, catalogue) & \multicolumn{1}{l}{ Dilution } & Antibody \\
\cline { 4 - 5 } & & & WB & HS \\
\hline CYP11A1 & rabbit & Cell Signaling Technology (Danvers, MA) & $1: 1000$ & $1: 200$ \\
SOX9 & rabbit & Abcam (San Francisco, CA) & $1: 1000$ & $1: 200$ \\
AMH & rabbit & Abcam (San Francisco, CA) & $1: 1000$ & ND \\
PDGFA & mouse & Santa Cruz (Santa Cruz, CA) & $1: 1000$ & ND \\
PCNA & rabbit & Abcam (San Francisco, CA) & ND & $1: 100$ \\
NR5A1 & mouse & Santa Cruz (Santa Cruz, CA) & $1: 1000$ & ND \\
LHGCR & rabbit & Abcam (San Francisco, CA) & $1: 1000$ & ND \\
HSD3B1 & mouse & Santa Cruz (Santa Cruz, CA) & $1: 200$ & ND \\
HSD17B3 & rabbit & Abcam (San Francisco, CA) & $1: 1000$ & ND \\
LC3-II & rabbit & Cell Signaling Technology (Danvers, MA) & $1: 1000$ & ND \\
p62 & rabbit & Cell Signaling Technology (Danvers, MA) & $1: 1000$ & ND \\
Beclin 1 & rabbit & Cell Signaling Technology (Danvers, MA) & $1: 1000$ & ND \\
GAPDH & rabbit & Abcam (San Francisco, CA) & $1: 1000$ & ND \\
\hline
\end{tabular}

$\mathrm{ND}=$ Not detected $; \mathrm{WB}=$ Western blot $; \mathrm{HS}=$ Histochemical staining.

Table.4 Information of primers 


\begin{tabular}{|c|c|c|c|c|}
\hline Gene name & $\begin{array}{l}\text { Primer } \\
\text { Direction }\end{array}$ & Sequences (5'to $\left.3^{\prime}\right)$ & $\begin{array}{l}\text { PCR } \\
\text { Size } \\
\text { (bp) } \\
\end{array}$ & Accession \\
\hline \multirow{2}{*}{ einizing hormone receptor } & Forward & CTGCGCTGTCCTGGCC & \multirow{2}{*}{103} & \multirow[t]{2}{*}{ NM_012978 } \\
\hline & Reverse & CGACCTCATTAAGTCCCCTGAA & & \\
\hline \multirow{2}{*}{ roidogenic factor 1} & Forward & CAGAGCTGCAAAATCGACAA & \multirow{2}{*}{187} & \multirow[t]{2}{*}{ NM_053344 } \\
\hline & Reverse & CCCGAATCTGTGCTTTCTTC & & \\
\hline \multirow[t]{2}{*}{ telet derived growth factor } & Forward & ACCTTGCACAATAACGGGAG & \multirow[b]{2}{*}{336} & \multirow[t]{2}{*}{ NM_012801 } \\
\hline & Reverse & CAGTTTGATGGACGGGAGTT & & \\
\hline \multirow[t]{2}{*}{ ıvenger receptor class B, } & Forward & ATGGTACTGCCGGGCAGAT & \multirow[b]{2}{*}{117} & \multirow[t]{2}{*}{ NM_031541 } \\
\hline & Reverse & CGAACACCCTTGATTCCTGGTA & & \\
\hline \multirow[t]{2}{*}{ roidogenic acute regulatory } & Forward & CCCAAATGTCAAGGAAATCA & \multirow[b]{2}{*}{187} & \multirow[t]{2}{*}{ NM_031558 } \\
\hline & Reverse & AGGCATCTCCCCAAAGTG & & \\
\hline \multirow[t]{2}{*}{ olesterol side chain cleavage } & Forward & AAGTATCCGTGATGTGGG & & \multirow[t]{2}{*}{ NM_017286 } \\
\hline & Reverse & TCATACAGTGTCGCCTTTTCT & 127 & \\
\hline \multirow[t]{2}{*}{ Hydroxysteroid dehydrogenase } & Forward & CCCTGCTCTACTGGCTTGC & & \multirow[t]{2}{*}{ NM_001007719 } \\
\hline & Reverse & TCTGCTTGGCTTCCTCCC & 189 & \\
\hline 50 family 17 subfamily a1 & $\begin{array}{l}\text { Forward } \\
\text { Reverse }\end{array}$ & $\begin{array}{l}\text { TGGCTTTCCTGGTGCACAATC } \\
\text { TGAAAGTTGGTGTTCGGCTGAAG }\end{array}$ & 90 & NM_012753 \\
\hline \multirow{2}{*}{ ulin-like 3} & Forward & GTGGCTGGAGCAACGACA & \multirow{2}{*}{102} & \multirow[t]{2}{*}{ NM_053680 } \\
\hline & Reverse & TGAAAGTTGGTGTTCGGCTGAAG & & \\
\hline \multirow{2}{*}{$\begin{array}{l}\text { 3-Hydroxysteroid } \\
\text { aydrogenase } 3\end{array}$} & Forward & TGAAAGTTGGTGTTCGGCTGAAG & & \multirow[t]{2}{*}{ NM_054007 } \\
\hline & Reverse & CCACAAGCCAATACAAACTAACT & 202 & \\
\hline \multirow{2}{*}{ liferating antigen } & Forward & CAACTTGGAATCCCAGAAC & \multirow{2}{*}{81} & \multirow[t]{2}{*}{ Y00047 } \\
\hline & Reverse & TAAGGTCCCGGCATATAC & & \\
\hline \multirow{2}{*}{ sert hedgehog } & Forward & AACCCCGACATAATCTTCA & \multirow{2}{*}{150} & NM_053367 \\
\hline & Reverse & CTCGTCCCAACCTTCAGT & & \\
\hline & Forward & GCССТААСССТTCAАCСА & & NM_012902 \\
\hline timulerian hormone & Reverse & GGGAATCAGAGCCAAACAGA & 82 & \\
\hline & Forward & TGCTGAACGAGAGCGAGAAG & & NM_080403 \\
\hline Y box 9 & Reverse & ATGTGAGTCTGTTCGGTGGC & 160 & \\
\hline & Forward & AAGTCTTCGGACGCAAGAAA & & NM_001169146 \\
\hline Iosomal protein S16 & Reverse & TTGCCCAGAAGCAGAACAG & 148 & \\
\hline
\end{tabular}

\section{Figures}


A.

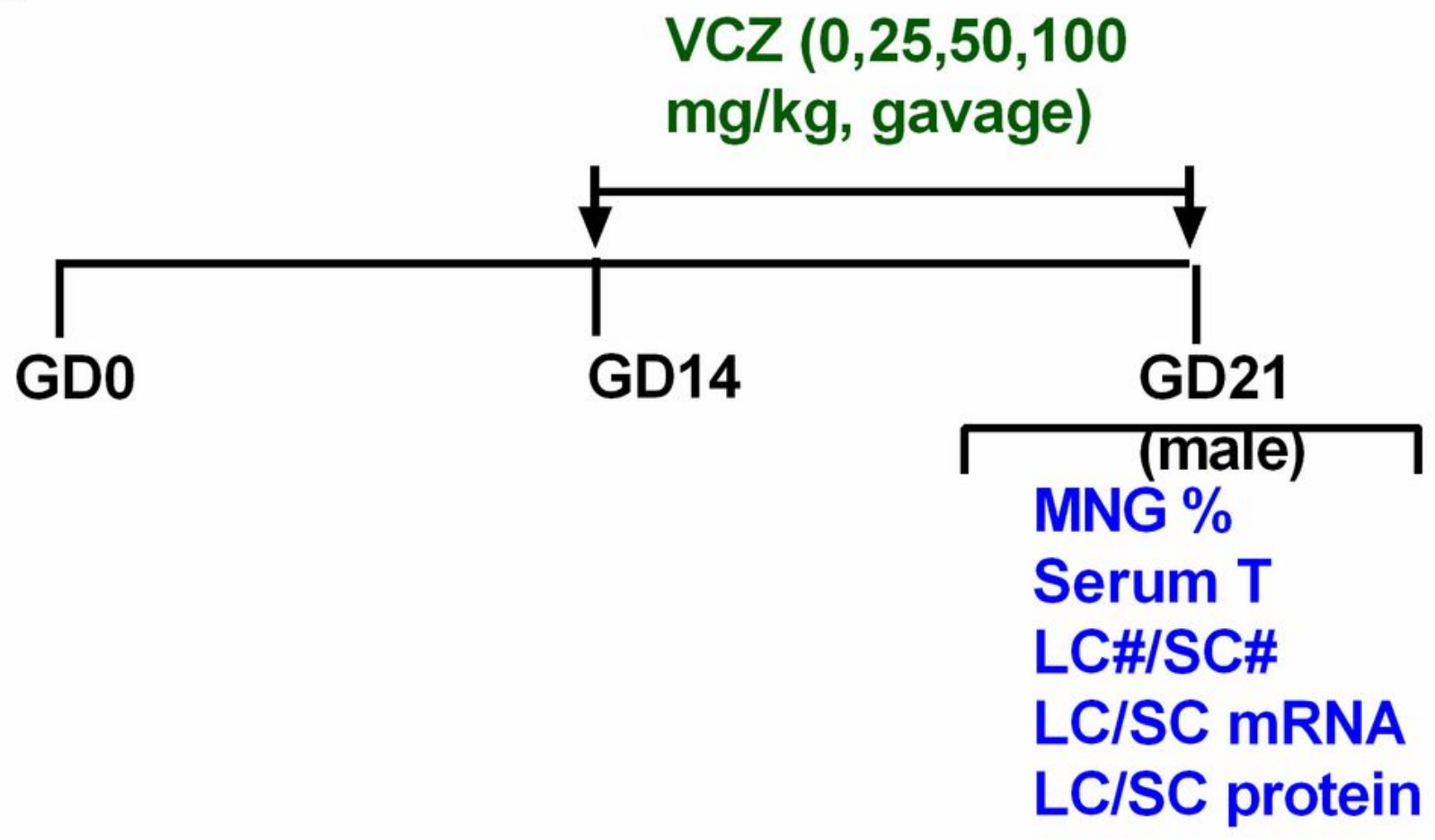

B.
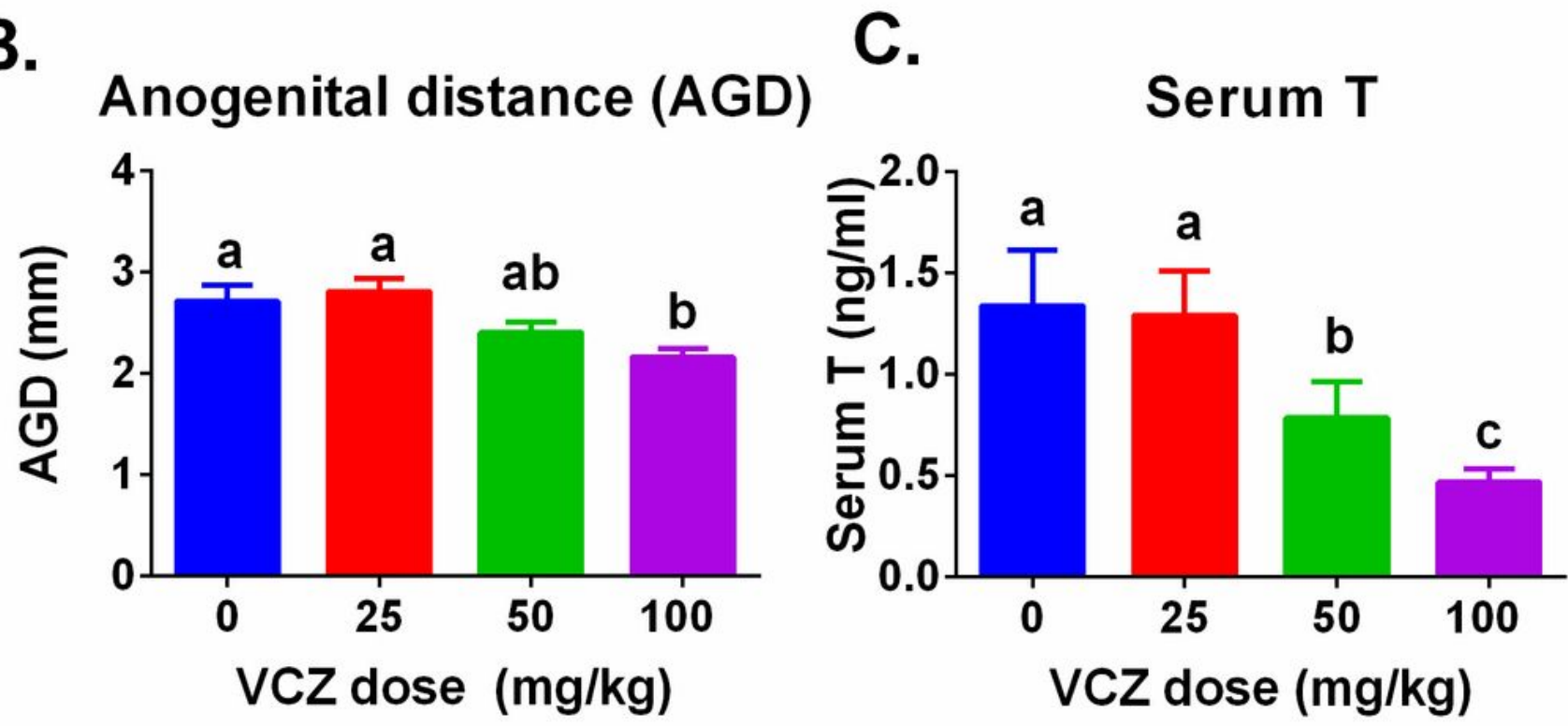

Figure 1

Regimen of vinclozolin and anogenital distance and serum testosterone levels after vinclozolin treatment Panel A, regimen: Vinclozolin (VCZ) was gavaged from gestational day (GD) 14 to 21 and the parameters for reproductive toxicity were examined. MNGs = multinucleated gonocyte, $L C=$ Leydig cell, SC =Sertoli cell; \# =number; Panel B, Anogenital distance (AGD); Panel C, serum testosterone (T) levels in male pups. 
Mean $\pm S E M, n=8$. Identical letters designate no significant difference between the two groups at $p<$ 0.05 .
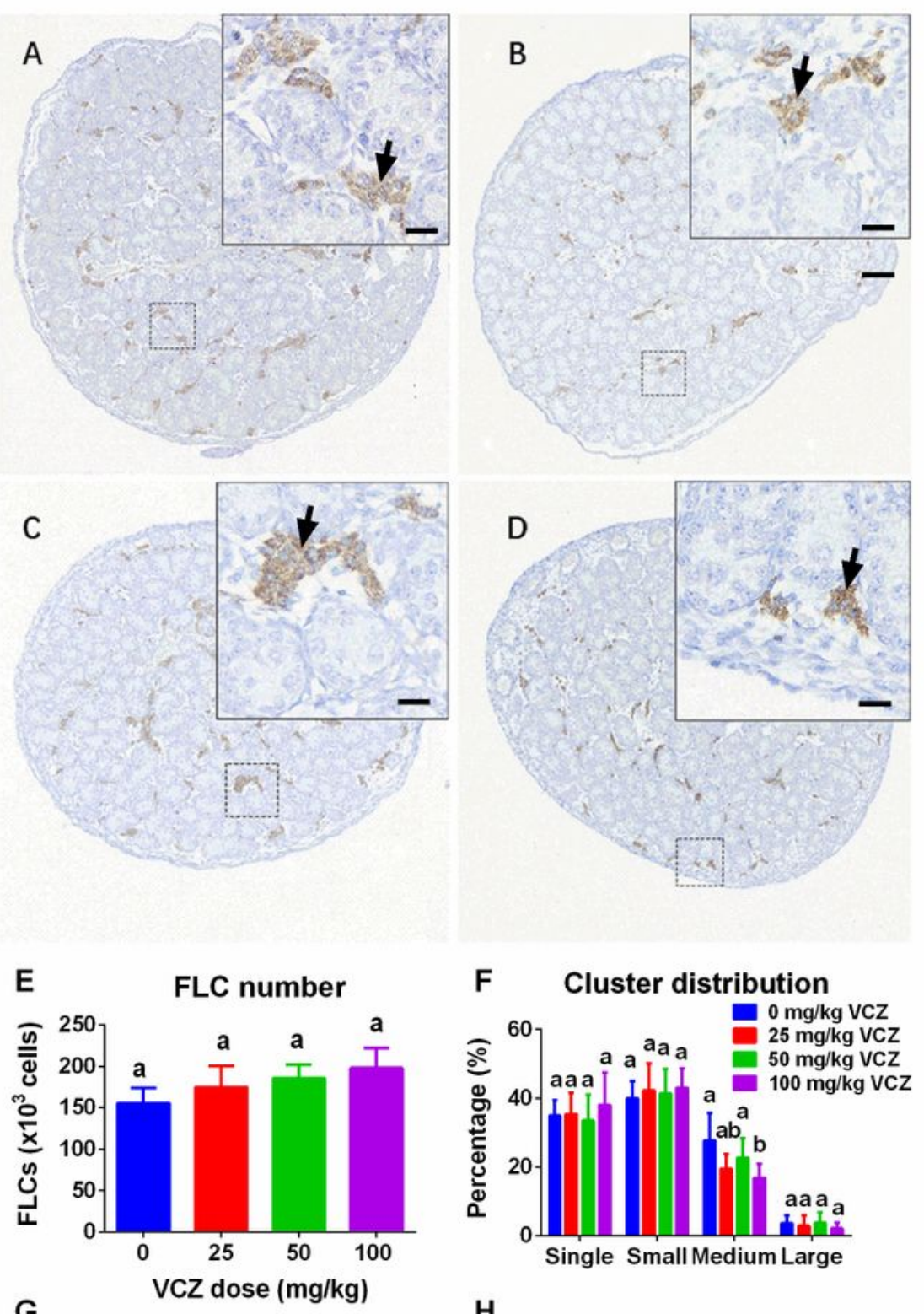

\section{F Cluster distribution}
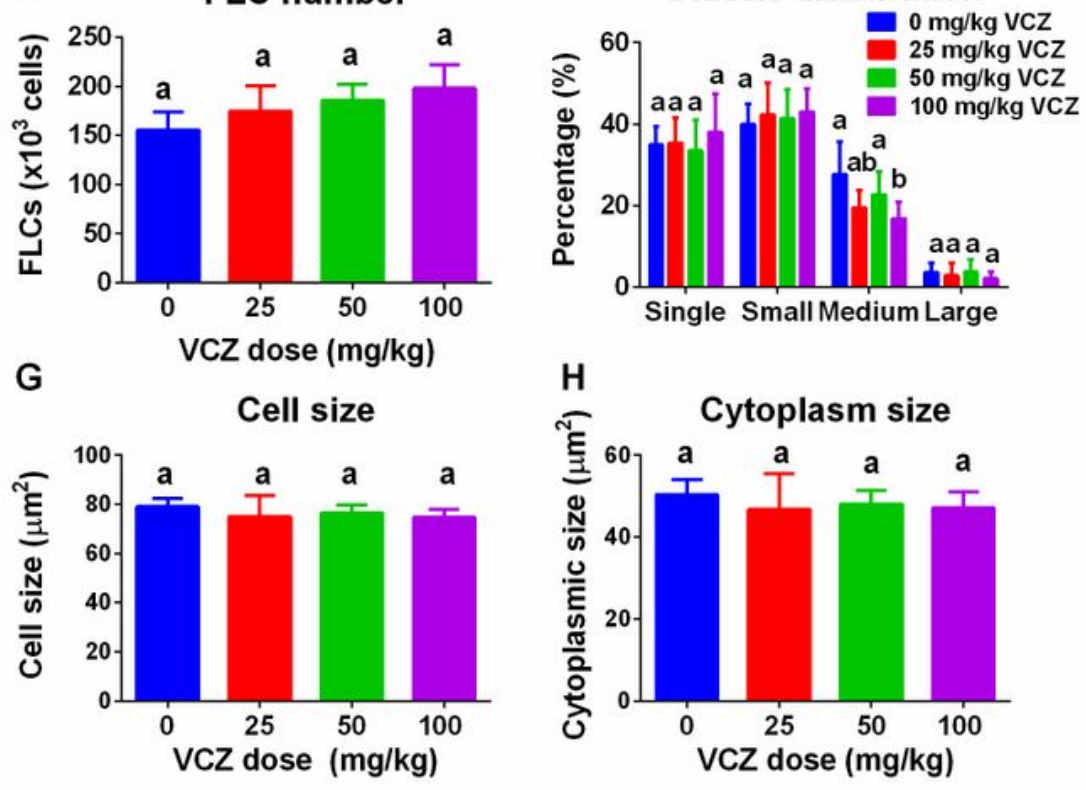

Figure 2

Fetal Leydig cell number, distribution, and cell metrics after vinclozolin treatment Panels A-D: Immunohistochemical staining of CYP11A1 at 0, 25, 50, and $100 \mathrm{mg} / \mathrm{kg} /$ day vinclozolin (VCZ); Arrow designates FLC; Bar = 20 m; Panel E, Fetal Leydig cell (FLC) number; Panel F, FLC distribution; Panel G, 
FLC cell size; Panel $H, F L C$ cytoplasmic size. Mean $\pm S E M, n=8$. Identical letters designate no significant difference between the two groups at $p<0.05$.

\section{SOX9/NR2F2}
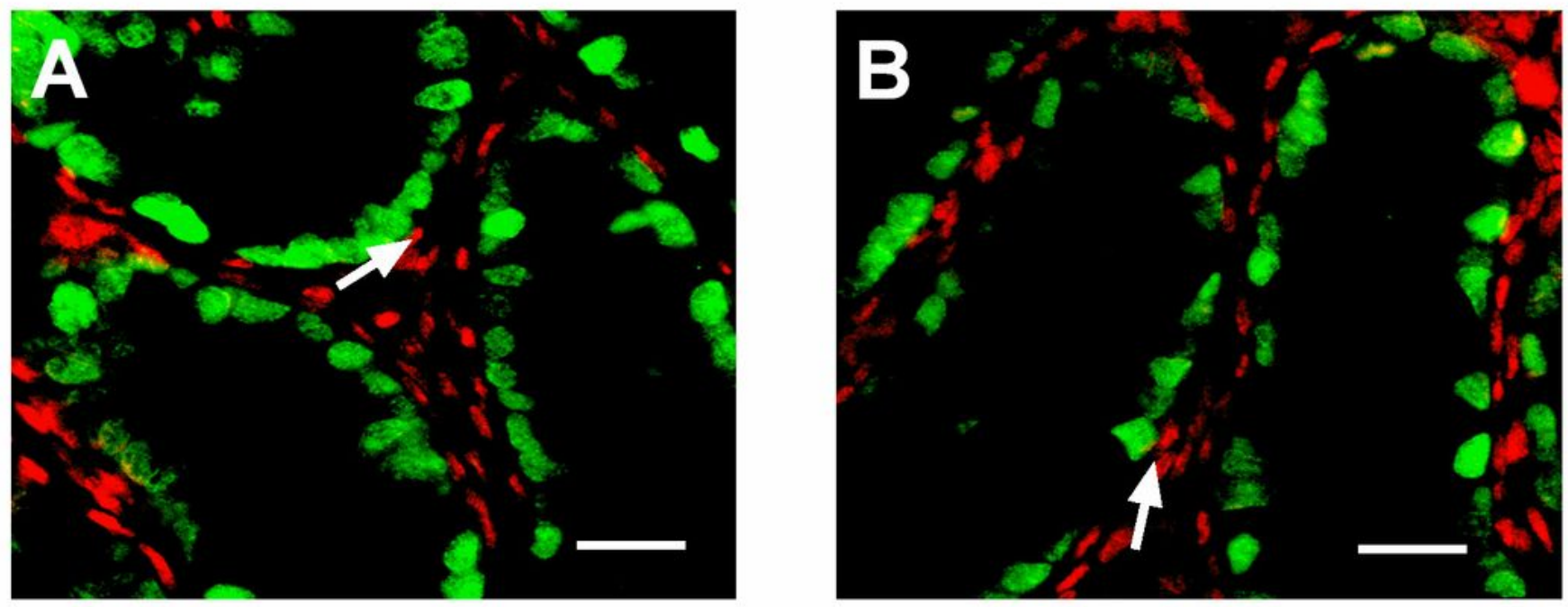

C

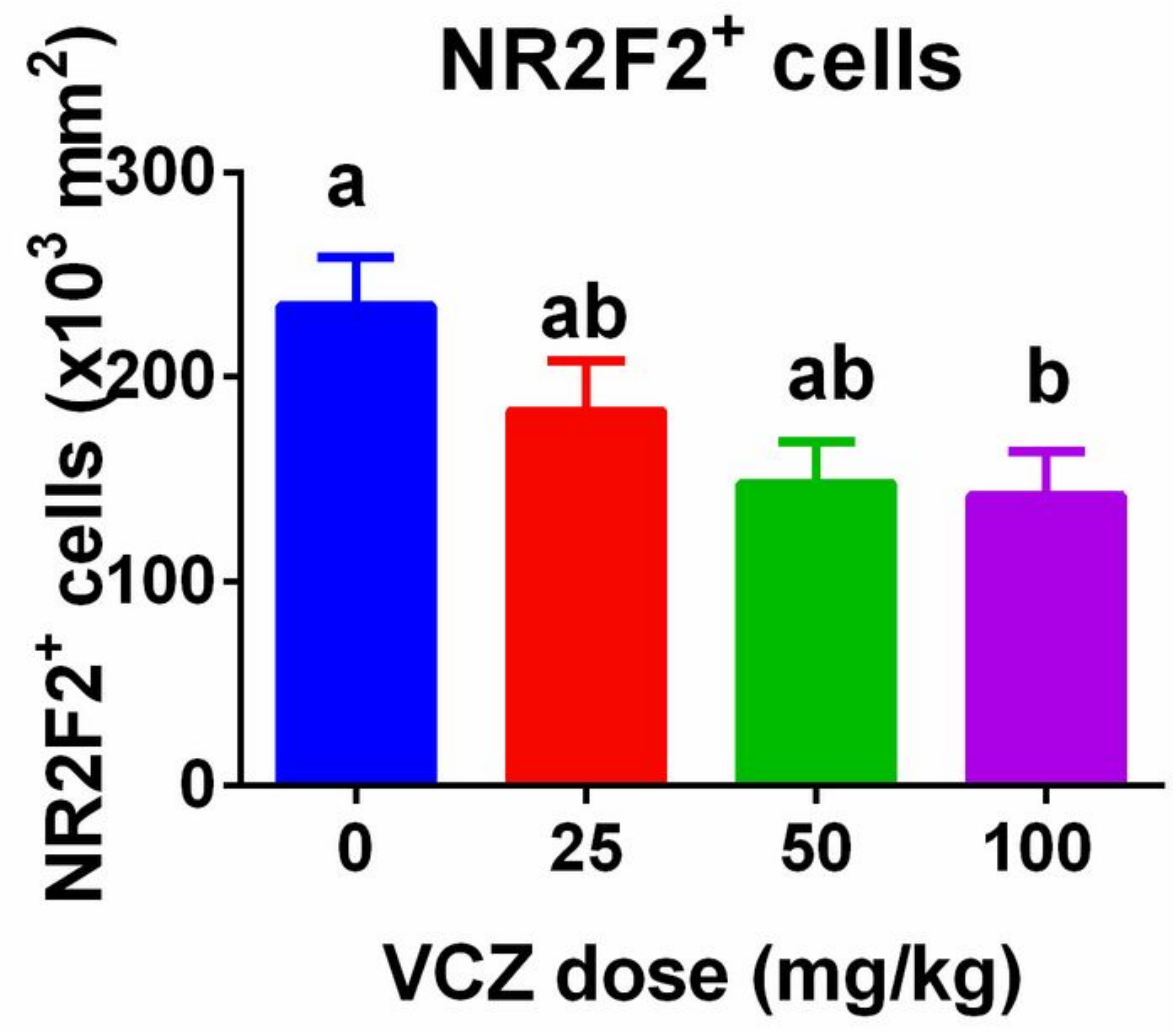

Figure 3

Figure 3 NR2F2-positive stem Leydig cell number after vinclozolin treatment Panels A-B: Representative immunofluorescent staining images of NREF2 at 0 and $100 \mathrm{mg} / \mathrm{kg} /$ day vinclozolin (VCZ); SOX9 (green color in the nucleus of the Sertoli cell) staining shows the seminiferous cord; Arrow designates NR2F2- 
positive stem Leydig cells (red color in the nucleus of the stem Leydig cell), which have spindle-shaped nuclei; Bar $=20 \mu \mathrm{m}$; Panel C, NR2F2-positive cell number. Mean $\pm \mathrm{SEM}, \mathrm{n}=8$. Identical letters designate no significant difference between the two groups at $p<0.05$.

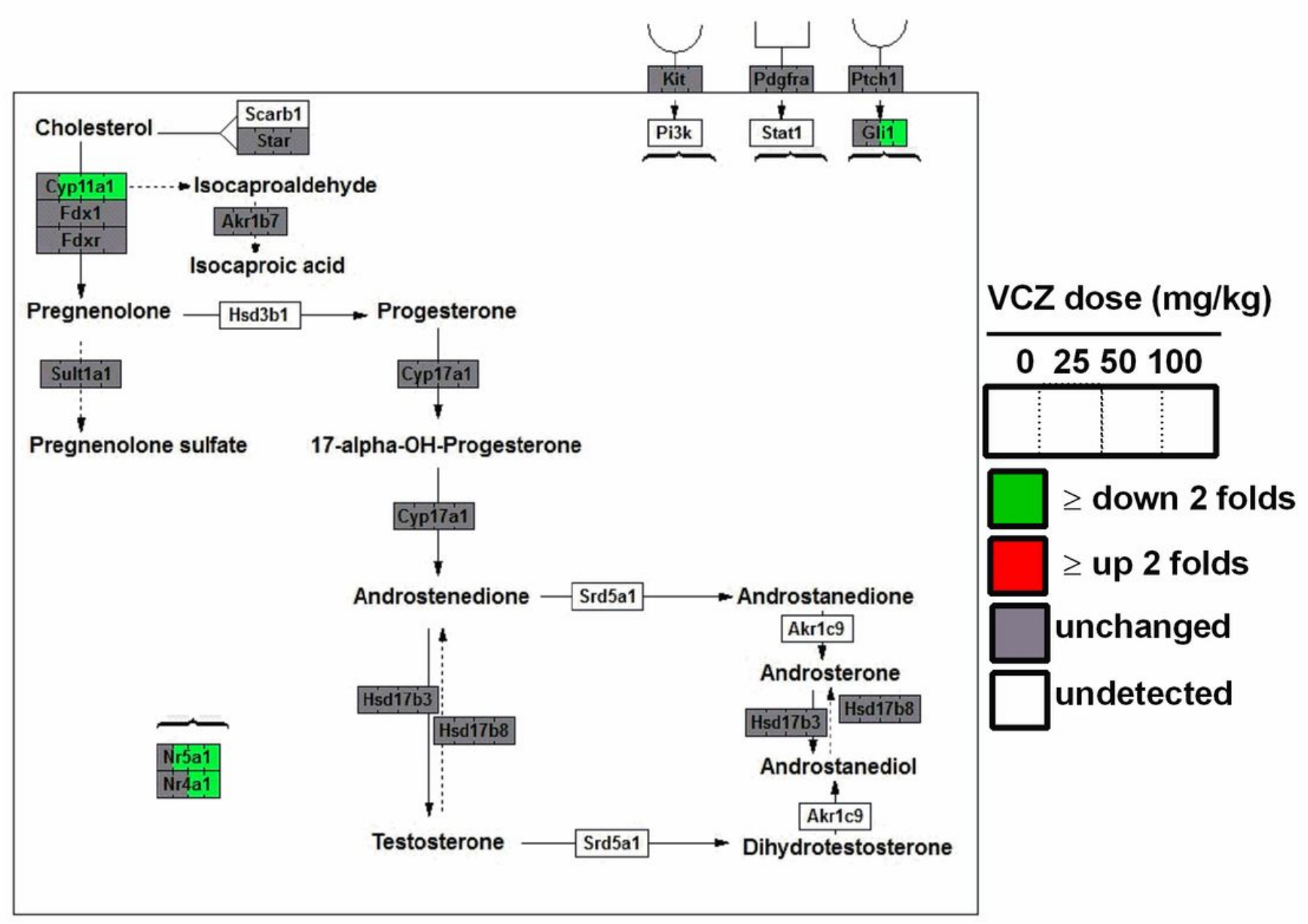

Figure 4

Figure 4 RNA-seq analysis of genes and GenMAPP2 analysis for steroidogenesis pathway after vinclozolin treatment $0,25,50$, and $100 \mathrm{mg} / \mathrm{kg}$ vinclozolin $(\mathrm{VCZ})$-treated testes $(\mathrm{n}=4)$ were compared. 
Lhgcr

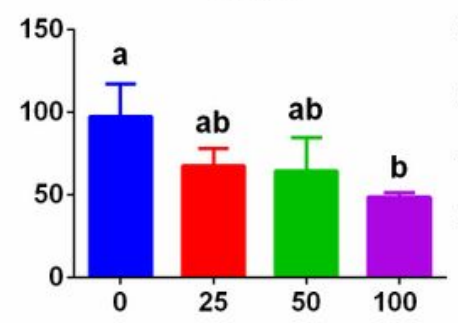

Cyp11a1

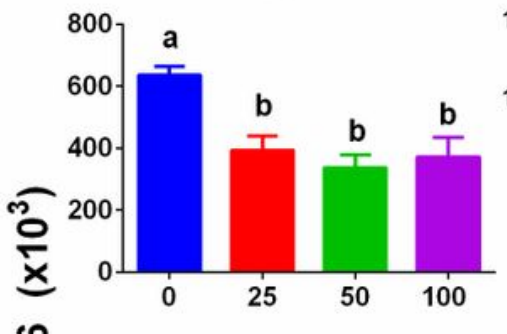

Hsd17b3
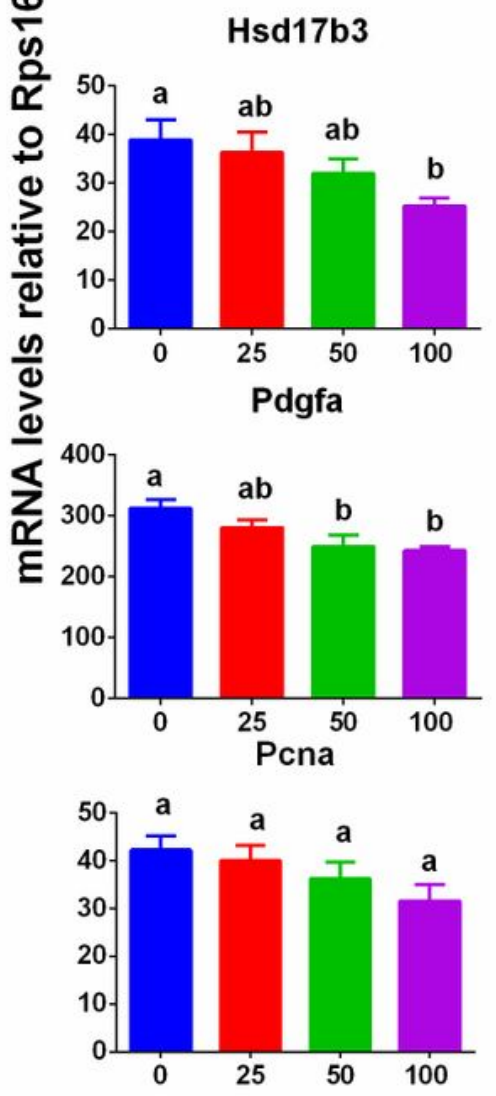

Scarb1

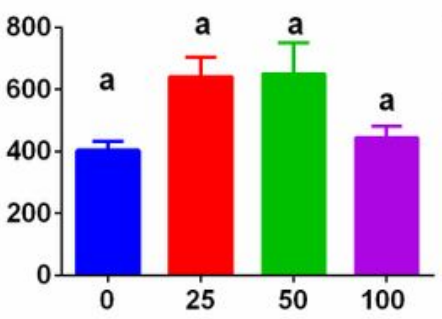

Hsd3b1

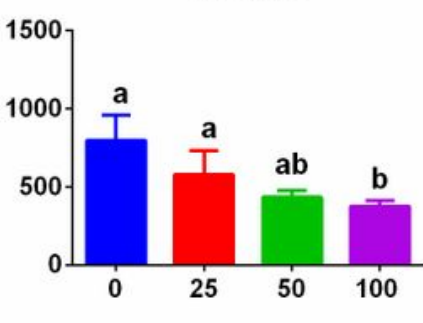

Insl3
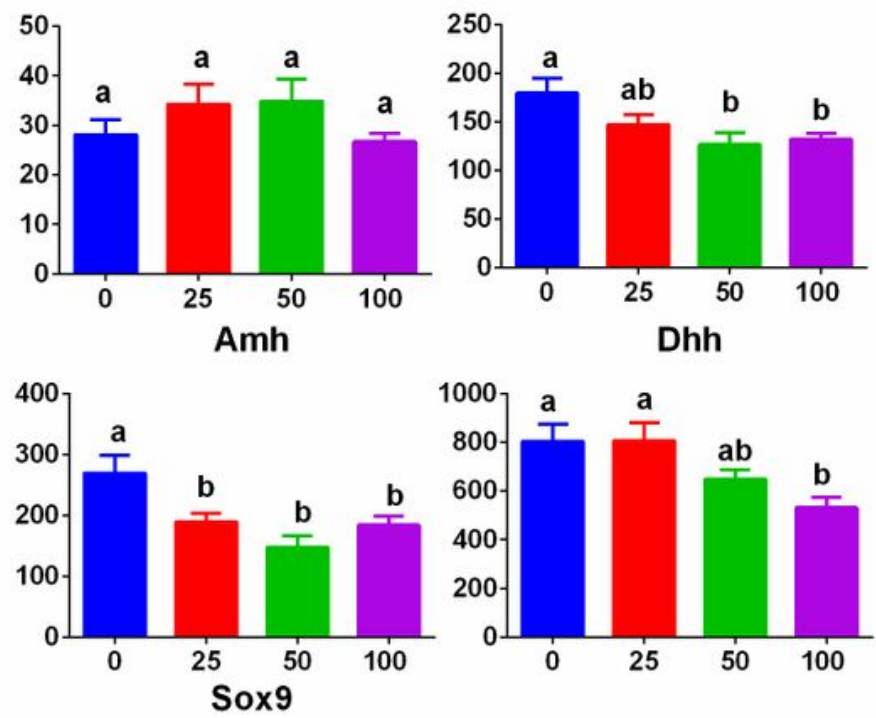

Cyp17a1

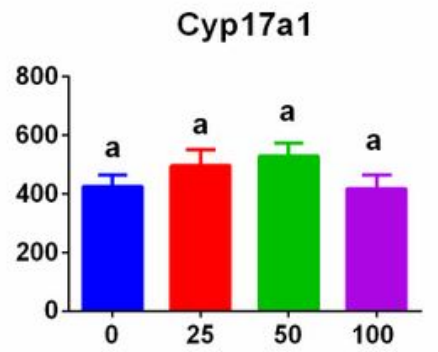

Nr5a1

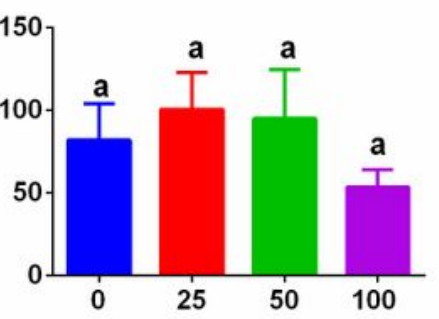

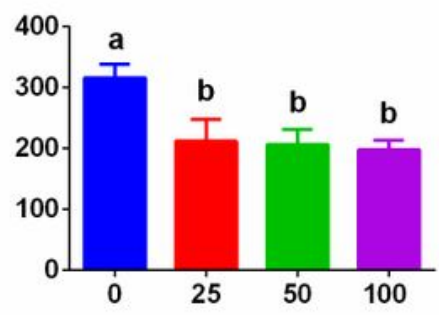

VCZ dose ( $\mathrm{mg} / \mathrm{kg})$

\section{Figure 5}

Figure 5 QPCR analysis of genes in the testes after vinclozolin treatment Gene (Lhcgr, Cyp11a1, Hsd3b1, Hsd17b3, Nr5a1, Pdgfa, Amh, Dhh, and Sox9) expression in 0, 25, 50, and $100 \mathrm{mg} / \mathrm{kg}$ vinclozolin (VCZ)treated testes was compared. Mean $\pm S E M, n=8$. Identical letters designate no significant difference between the two groups at $p<0.05$. 
A

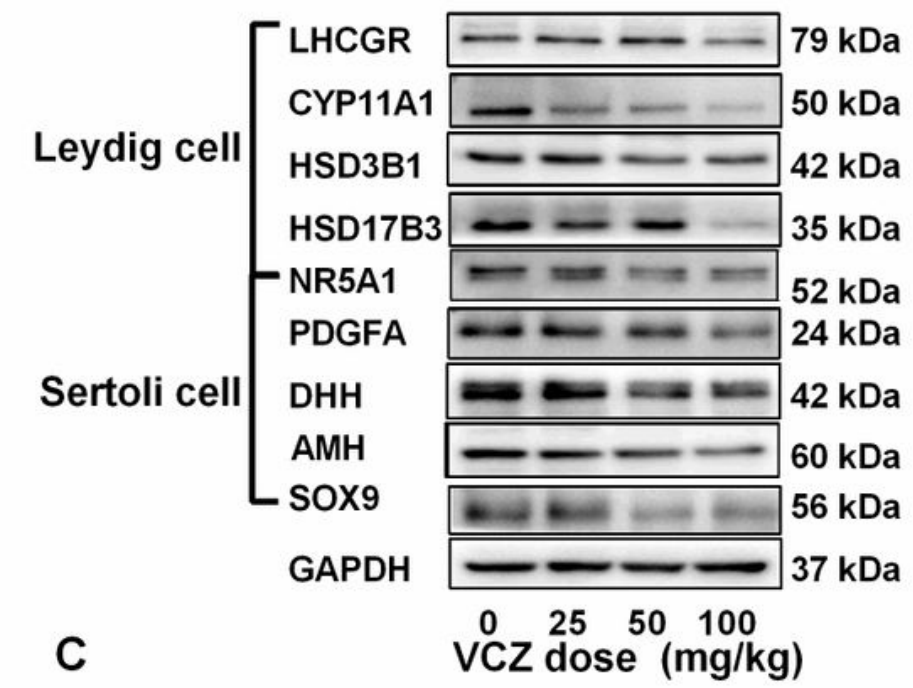

LHGCR

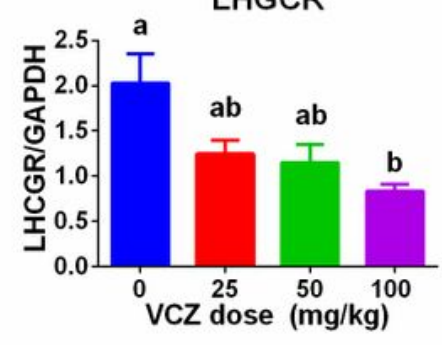

HSD17B3

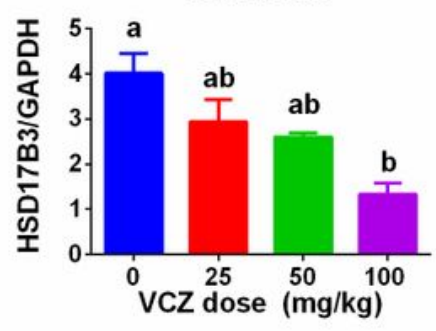

$\mathrm{DHH}$

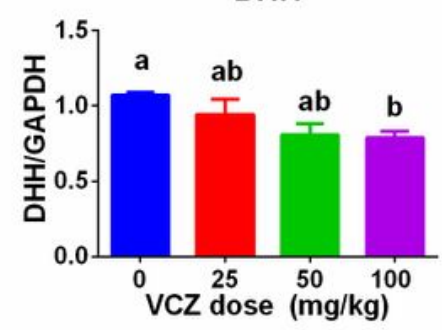

B

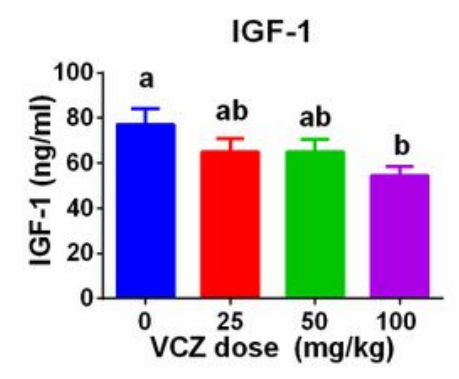

HSD3B1

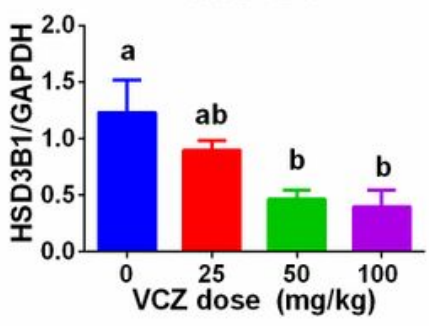

PDGFA

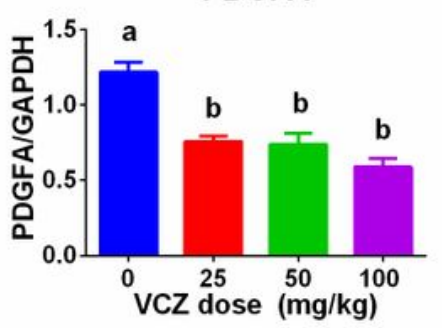

sox 9

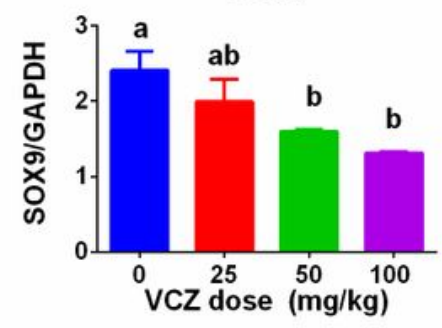

\section{Figure 6}

Figure 6 Western blotting analysis of proteins in the testes and ELISA for serum IGF-1 after vinclozolin treatment $0,25,50$, and $100 \mathrm{mg} / \mathrm{kg}$ vinclozolin (VCZ)-treated testes were compared. Panel A, the image of Western blot; Panel B, Serum IGF-1, Mean \pm SEM, $n=8$; Panel C, quantitative measurement of Western blotting data, Mean $\pm \mathrm{SEM}, \mathrm{n}=3-4$. Identical letters designate no significant difference between the two groups at $p<0.05$. 
A.

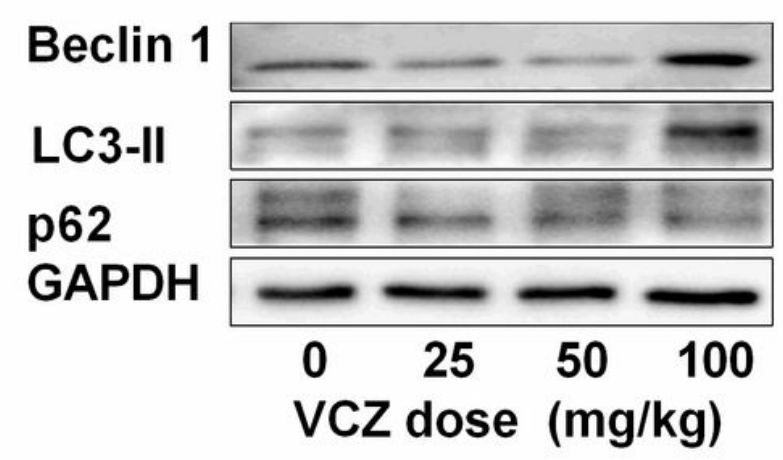

c.

LC3-II

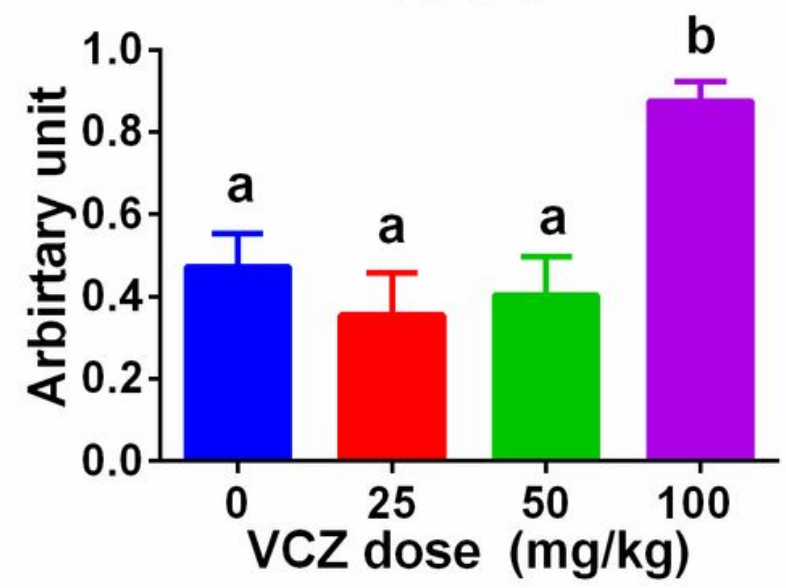

B. Beclin1

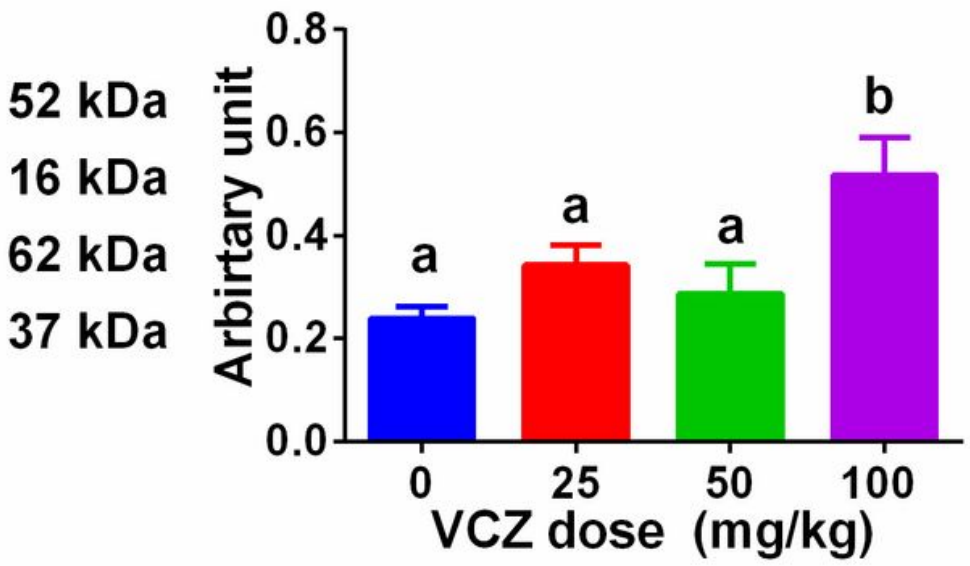

D.

p62

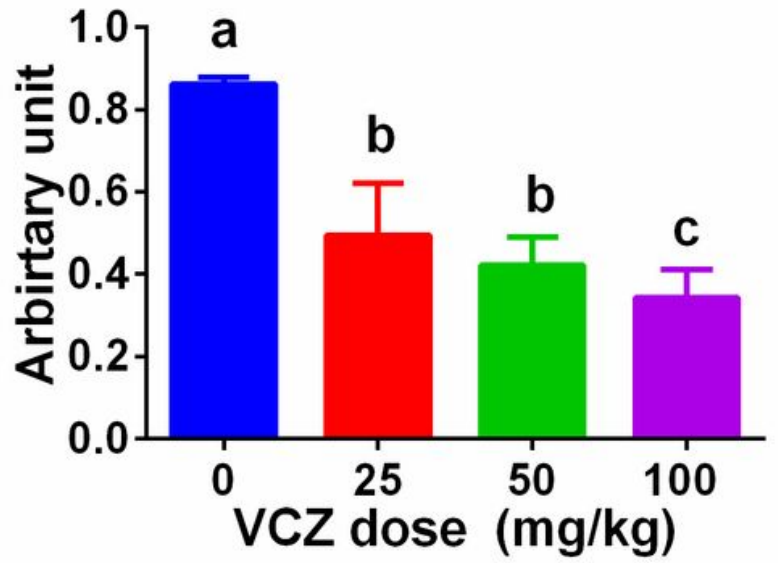

Figure 7

Figure 7 Western blotting analysis of autophagy-related proteins in the testes after vinclozolin treatment $0,25,50$, and $100 \mathrm{mg} / \mathrm{kg}$ vinclozolin (VCZ)-treated testes were compared. Panel A, the image of Western blotting bands; Panels B-D, quantitative measurement of beclin 1, LC3-II, and p62 protein levels, respectively. Mean $\pm S E M, n=3$. Identical letters designate no significant difference between the two groups at $p<0.05$.

\section{Supplementary Files}

This is a list of supplementary files associated with this preprint. Click to download.

- SubFig3.tif

- SupplementarymaterialS1.docx 
- SubFig2.tif

- SubFig1.tif

- SubFig5.tif

- SubFig4.tif

- SupFIG6.tif 